\title{
Odnos zborskih aktivnosti i dobrobiti pjevača amatera
}

https://doi.org/10.31192/np.19.3.10

UDK: 78.087.68-027.562

379.8

Tihana Škojo*

tihana.skojo@aukos.hr

https://orcid.org/0000-0003-4709-3139
Izvorni znanstveni rad / Original scientific paper

Primljeno: 2. ožujka 2021.

Prihvaćeno: 10. lipnja 2021.

Unatoč aktualnim pojavnostima u društvu koje sustavno utječu na smanjenje slobodnoga vremena kod svih društvenih skupina, zborsko je pjevanje zadržalo svoju bogatu tradiciju $i$ mjesto najzastupljenije slobodne aktivnosti u kojoj pojedinci uspješno iznalaze načine da zadovolje svoju potrebu za aktivnošću, socijalizacijom, da kvalitetno zadovolje zanimanje za glazbu i glazbeno stvaralaštvo te da se dodatno afirmiraju u društvu. Na temelju dosadašnjih istraživanja ukazujemo na odnos glazbenih aktivnosti i dobrobiti pojedinca, povezanost pozitivnih emocija s pjevanjem u zboru, što se očituje u promjeni fiziološkoga statusa pjevača te na razvoj glazbenih vještina i poboljšanje psihofizičkoga stanja pjevača. Vodeći se iskustvima iz ranijih svjetskih istraživanja, a radi utvrđivanja odnosa aktivnosti zborskoga pjevanja i dobrobiti pjevača amatera provedeno je istraživanje u kojemu se ispitala duljina pjevačkog staža, zadovoljstvo životom, doprinos pjevanja subjektivnom osjećaju dobrobiti te percipirana procjena fizičke, emocionalne, socijalne i duhovne dobrobiti. Dobiveni rezultati potvrduju da pjevanje u zboru pruža brojna osobna poboljšanja kod pjevača. Pjevači procjenjuju da je najsnažnija dobrobit od zborskog pjevanja povezana s emocionalnim, zatim socijalnim pa fizičkim i najmanje s područjem duhovne dobrobiti. Zborsko pjevanje, osim primarne umjetničke funkcije, pridonosi emocionalnoj, društvenoj i fizičkoj dobrobiti kao važnom cilju slobodnih aktivnosti $i$ života uopće.

Ključne riječi: zborsko pjevanje, dobrobit, slobodno vrijeme.

\footnotetext{
* Doc. dr. sc. Tihana Škojo, Sveučilište J. J. Strossmayera u Osijeku, Akademija za umjetnost i kulturu, Kralja Petra Svačića 1F, HR-31000 Osijek.
} 


\section{Uvod}

Slobodno je vrijeme, kao vrijeme istraživanja vlastitih potencijala, pozitivnoga razvoja, socijalizacije i stvaralačkoga potvrđivanja ličnosti ${ }^{1}$, važna odrednica života svakoga pojedinca. To je područje svakodnevnoga života, kreativan životni i vremenski prostor u kojem se pojedinac osjeća prirodno, spontano, zadovoljno i ostvareno. ${ }^{2}$ Iako slobodno vrijeme u životu suvremenoga čovjeka zauzima tek malen dio njegova vremena, to je upravo ona kategorija koja ima »vitalne funkcije prema kojima se može procjenjivati kvaliteta i zadovoljstvo životom ljudi neovisno o njihovoj dobi«. ${ }^{3}$

Sve veći zahtjevi modernoga društva i ubrzan tempo života izmijenili su načine provođenje slobodnoga vremena i aktivnosti slobodnoga vremena koje pojedinci odabiru sukladno osobnim preferencijama, ali je zborsko pjevanje, usprkos svim izazovima današnjice, zadržalo vodeće mjesto među kulturnim aktivnostima. Zborsko je pjevanje svojevrstan fenomen globalnih razmjera koji postoji u gotovo svim civiliziranim svjetskim kulturama. Iz rezultata Studije Chorus America razvidno je da 23,5 milijuna Amerikanaca tjedno sudjeluje u zborskim aktivnostima. ${ }^{4}$ Zborski dirigent Colin Durrant ukazuje na dugu tradiciju zborskoga pjevanja u Velikoj Britaniji, Norveškoj, Finskoj i Švedskoj, navodeći da se za zborske aktivnosti, primjerice, samo u Švedskoj odlučuje gotovo 600.000 pojedinaca. ${ }^{5}$

Zborsko je pjevanje kulturna i umjetnička aktivnost u kojoj se okupljaju osobe koje pokazuju interes za pjevanje i glazbu radi glazbenoga, intelektualnoga i osobnoga razvoja i rasta. Sudjelovanjem u ovoj aktivnosti pojedinac permanentno usvaja i razvija nova glazbena znanja i vještine te unaprjeđuje svoje glazbene sposobnosti. Istovremeno oblikuje kulturna i umjetnička djela ${ }^{6}$ te prenosi i održava tradiciju. ${ }^{7} \mathrm{U}$ zborskom je pjevanju dominantno usvajanje glazbenih sadržaja, pjesama i razvijanje pjevačkih vještina. Osim toga, važan element u radu s pjevačkim zborom odnosi se na međusobno usklađivanje pje-

${ }^{1}$ Usp. Vlatko PREVIŠIĆ, Slobodno vrijeme između pedagogijske teorije i odgojne prakse, $\mathrm{Na}$ predak, 141 (2000) 4, 403-410.

${ }^{2}$ Usp. Ante FULGOSI, Psihologija ličnosti, Zagreb, Školska knjiga, 1987.

${ }^{3}$ Usp. Vesnica MLINAREVIĆ, Zlatko MILIŠA, Ana PROROKOVIĆ, Slobodno vrijeme mladih u procesima modernizacije-usporedba slavonskih gradova i Zadra, Pedagogijska istraživanja, 4 (2007) 1, 81-99, 82.

${ }^{4}$ Usp. Cindy L. BELL, Update on community choirs and singing in the United States, International Journal of Research in Choral Singing, 2 (2004) 1, 39-52.

${ }^{5}$ Usp. Colin DURRANT, Shaping identity through choral activity: Singers' and conductors' perceptions, Research Studies in Music Education, 24 (2004)1, 88-98.

${ }^{6}$ Usp. PETRA PEJIĆ PAPAK, Sabina VIDULIN ORBANIĆ, Anita RONČEVIĆ, Uloga organiziranih aktivnosti u kulturnom životu učenika, Život i škola, 28 (2012) 2, 188-203.

7 Usp. Colin DURRANT, Shaping identity through choral activity. Singers' and conductors' perceptions, Research Studies in Music Education, 24 (2004)1, 88-98. 
vača, uspostavljanje harmonične povezanosti na razini boja glasa, disanja te interpretacijskih izražajnih sredstava. ${ }^{8}$

U zborskome je pjevanju estetsko iskustvo, estetski odgoj i oblikovanje estetskoga mišljenja neodvojiv dio cijeloga procesa koji je razvidan u svim fazama, od odabira literature, interpretacije djela i izvedbe do krajnjega osobnoga umjetničkoga doživljaja. Voditelji se zbora već pri odabiru zborskoga repertoara vode kriterijima koji će, uz atraktivnost, potvrđivati i estetsku vrijednost skladbe te kod pjevača razvijati sposobnosti opažanja, doživljavanja, vrednovanja i ostvarivanja lijepoga. Završetkom cijeloga dugotrajnoga procesa uvježbavanja, interpretacijom skladbe, u trenutcima kada glazba obgrli pjevače, umjetnički, estetski, ali i emocionalni doživljaj dostižu svoj vrhunac.

Cjelokupno je zborsko iskustvo iznimno pozitivan doživljaj koji pjevačima pruža mogućnost da radom na zborskim pokusima te javnim djelovanjem zbora utječu i na stvaranje kvalitetnoga estetski obojenoga pozitivnoga društvenoga ozračja, u privatnim životima pjevača i u životu cijele zajednice. ${ }^{9}$ Osim estetskoga utjecaja, zborsko pjevanje, posebice javni nastupi, ima dodatni motivacijski učinak na pjevače i stalan su poticaj pjevačima za daljnji predaniji rad i stvaranje boljih izvedbi. ${ }^{10}$

Brojni autori naglašavaju da je u zborskome pjevanju društvena komponenta neodvojiva od glazbene. ${ }^{11}$ Istražujući razloge uključivanja pjevača u amaterske zborove, zaključuju da su primarni razlozi glazbene prirode povezani sa zadovoljavanjem želje za pjevanjem i glazbeno-estetskim ostvarenjima, ali se odmah nakon glazbenih razloga nalazi ostvarivanje prijateljstva među članovima zbora, druženje te putovanja i susreti s drugim zborovima i drugi socijalni razlozi. ${ }^{12}$ Iako je diljem svijeta u posljednjem desetljeću obavljen velik broj istraživanja usmjerenih na društvenu i psihološku prednost aktivnosti pjevanja, ${ }^{13} \mathrm{u}$

${ }^{8}$ Usp. Antoaneta RADOČAJ-JERKOVIĆ, Zborsko pjevanje u odgoju i obrazovanju, Osijek, Umjetnička akademija u Osijeku, 2017.

${ }^{9}$ Usp. Antoaneta RADOČAJ-JERKOVIĆ, Tihana ŠKOJO, Majda MILINOVIĆ, Zborsko pjevanje kao oblik neformalnog učenja i njegov utjecaj na formiranje dječjih glazbenih preferencija, Školski vjesnik: časopis za pedagogiju i praksu, 67 (2018) 2, 311-330.

${ }^{10}$ Usp. Roger PALMER, Questions arising from the views of some members of four amateur clasical music organizations, International Journal of Community Music, 1 (2008) 2, 203-216.

${ }^{11}$ Usp. Dirk MOELANTS, The Influenceof an Audience on Performers. A Comparison Between Rehearsal and Concert Using Audio, Video and Movement Dana, Journal of New Music Research, 41 (2012) 1, 67-78.

${ }^{12}$ Usp. Zdenka WEBER, Članstvo u amaterskom pjevačkom zboru - to nije samo pjevanje, Ars Choralis, 1 (2010), 1-16.

${ }^{13}$ Usp. Betty A. BAILEY, Jane W. DAVIDSON, Amateur group singing as a therapeutic instrument, Nordic Journal of Music Therapy, 12 (2003)1, 18-32; Betty A. BAILEY, Jane W. DAVIDSON, Effects of group singing and performance for marginalized and middle-class singers, Psychology of Music, 33 (2005) 3, 269-303; Stephen CLIFT, Grenville HANCOX, The significance of choral singinf for sustaining psychological wellbeing. Findingds from a survey of choristers in England, Australia and Germany, Music and Health, 3 (2010) 1, 79-96; Gene COHEN i dr., The impact of professionally conducted cultural programs on the physical health, mental health, and social functioning of older adults, Gerontologist, 46 (2006) 726-734. 
Hrvatskoj, unatoč iznimno bogatoj tradiciji i svjetskoj prepoznatosti hrvatskih zborova, istraživanja fenomena odnosa zborskih aktivnosti i subjektivne dobrobiti pjevača još uvijek nisu provedena.

Uporaba glazbe radi ostvarivanja dobrobiti pojedinaca razvidna je još iz vremena stare Grčke, ${ }^{14}$ a tek se u posljednjih pedeset godina počinje detaljnije znanstveno istraživati složen odnos pjevanja i dobrobiti kroz aspekte zajedničkoga glazbenoga iskustva, oblikovanja međuljudskih odnosa i jačanja samopoštovanja. Upravo je zbog terapeutskoga djelovanja pjevanja većina istraživanja o zborskome pjevanju uključivala sudionike iz specifičnih populacija. U istraživanju koje se odnosilo na pjevačke aktivnosti kod prijestupnika, zaključeno je da pjevanje potiče osjećaj pripadnosti, lojalnosti i na taj način omogućava poboljšanje njihovih socijalnih odnosa i općega odnosa prema društvu. ${ }^{15} \mathrm{U}$ istraživanju koje je obuhvaćalo pjevače amatere, korisnike za doma za starije, naglašeno je značajno smanjenju razine anksioznosti i depresije. ${ }^{16}$ Tijekom longitudinalnoga kvalitativnoga istraživanja utjecaja zborskoga pjevanja na dobrobit odraslih osoba s oštećenjem mentalnoga zdravlja izdvojene su tri najznačajnije teme koje su se tijekom intervjua iskristalizirale, a to su: osobni utjecaj pjevanja (pozitivne emocije, bolja regulacija emocija i duhovno iskustvo), društveni utjecaj (povezanost s ostalim pjevačima, povezanost s publikom, bolje funkcioniranje u svakodnevnome životu) te širi funkcionalni ishodi (zdravstvena korist, kvalitetnija dnevna rutina i dr.). ${ }^{17}$

Nizu kvalitativnih istraživanja odnosa dobrobiti pjevača i zborskih aktivnosti, istraživanjima sivoga ${ }^{18}$ područja, dominantno između glazbenoga obrazovanja i glazbene terapije, za koji zanimanje pokazuju temeljno glazbeni pedagozi s gledišta ukazivanja na važnost glazbeno-pedagoškoga pristupa, ali i glazbeni terapeuti s gledišta terapijske intervencije, kao i psiholozi, sociolozi i brojni drugi znanstvenici, ${ }^{19}$ pridružila se Laya Silber, koja je provela longitudinalno istraživanje u ženskome zatvoru u Izraelu. Rezultatima istraživanja ukazuje da su zborska zajednica, njezina pravila, interakcije, jezik, ali i kodovi

\footnotetext{
${ }^{14}$ Usp. Mitchell L. GAYNOR, Sounds of healing. A physician reveals the therapeutic power of sound, voice and music, New York, Broadway Books, 1999.

${ }^{15}$ Usp. Alicia A. CLAIR, George HELLER, Willem van de Wall. Organizer and innovator in music and music therapy, Journal of Research in Music Education, 37 (1989) 3, 166-178.

${ }^{16}$ Usp. Diane M. HOUSTON, Kevin J. McKee, Henry MARSH, Using humour to promote psychological wellbeing in residential homes for older people, Aging and Mental Health, 2 (1998) 4, 328-332.

${ }^{17}$ Usp. Genevieve A. DINGLE i dr., 'To be heard'. The social and mental health benefits of choir singing for disadvantaged adults, Psychology of Music, 41 (2012) 4, 1-17.

${ }^{18}$ Usp. Laya SILBER, Bars behind bars. The impact of a women's prison choir on social harmony, Music Education Research, 7 (2005) 2, 251-271.

${ }^{19}$ Usp. Gianna CASSIDY, Raymond A. R. MACDONALD, The effects of music on time perception and performance of a driving game, Scandinavian Journal of Psychology, 51 (2010) 6, 455464.
} 
jedinstveno i specifično područje terapeutskoga djelovanja koje pruža pozitivnu korist za tu populaciju. ${ }^{20}$

Bailley kvalitativnim istraživanjem ispituje odnos zborskoga pjevanja i dobrobiti na dvadeset beskućnika iz skloništa u Montrealu. ${ }^{21}$ Iako je zbor ostvario značajne uspjehe na nacionalnoj i međunarodnoj razini, odgovori su pjevača isključivo bili usmjereni na psihološku i fiziološku dobrobit od aktivnosti pjevanja. Sljedećim istraživanjem potvrđuje ranije dobivene hipoteze uspoređujući odnos dobrobiti i zborskoga pjevanja u paralelnom radu s dva kanadska zbora. ${ }^{22} \mathrm{U}$ prvome su zboru sudjelovali pjevači rubnoga društvenoga sloja, dok su u drugome sudjelovali pjevači iz srednjega i višega društvenoga sloja. Zaključuje da su pjevači iz višega društvenoga sloja u zborskim aktivnostima dominantno usmjereni na razvijanje glazbenih vještina te su prilikom nastupa promišljali o ispunjavanju visokih glazbenih standarda, za razliku od pjevača iz nižega društvenoga sloja koji su nastup doživljavali isključivo kao prigodu za ostvarivanjem zajedništva. Iako su pjevači iz oba zbora iskazali pozitivnu emocionalnu korist od zborskoga pjevanja, uloga prijateljstva i zajedništva kod pjevača nižega društvenoga sloja bila je značajno važnija.

Recentno istraživanje povezuje aktivnosti zborskoga pjevanja s promjenama u imunološkome sustavu pjevača tijekom uvježbavanja i javne izvedbe Beethovenove Mise Solemnis u $D$-duru..$^{23}$ Rezultatima istraživanja, u kojemu su mjerili razinu imunoglobulina A kod pjevača prije i nakon probe, autori su potvrdili utjecaj zborskoga pjevanja na fiziološke varijable dobrobiti pjevača, pojačanu aktivnost imunološkoga sustava. Na fiziološke promjene ukazuje i istraživanje u kojemu se ističe međusobna sinkroniziranost u disanju i otkucajima srca kod pjevača u zboru. ${ }^{24}$

Svaki napor istraživača treba smatrati korisnim pokušajima da se razjasni odnos aktivnosti zborskoga pjevanja i utjecaja na dobrobit pojedinca, ali i dobrim polaznim hipotezama za buduća istraživanja. Također je rasvjetljavanje ovoga fenomena prilika da se istaknu uloga i važnost voditelja zborova, svih onih brojnih glazbenih pedagoga zahvaljujući čijim je naporima, iznimnoj kompetentnosti, motiviranosti, ustrajnosti te emotivnom i umjetničkom zanosu zborsko pjevanje opstalo kao vodeća aktivnost slobodnoga vremena.

\footnotetext{
${ }^{20}$ Usp. Laya SILBER, Bars behind bars. The impact of a women's prison choir on social harmony, Music Education Research, 7 (2005) 2, 251-271.

${ }^{21}$ Usp. Betty A. BAILEY, Jane W. DAVIDSON, Amateur group singing as a therapeutic instrument, Nordic Journal of Music Therapy, 12 (2003) 1, 18-32.

${ }^{22}$ Usp. Betty A. BAILEY, Jane W. DAVIDSON, Effects of group singing and performance for marginalized and middle-class singers, Psychology of Music, 33 (2005) 269-303.

${ }^{23}$ Usp. Robert J. BECK i dr., Choral singing, performance perception, and immune system changes in salivary immunoglobulin A and cortisol. Music Perception, 18 (2000) 87-106.

${ }^{24}$ Usp. Björn VICKHOFF i dr., Music structure determines heart rate variability of singers, Frontiers in Psychology, 4 (2013) 1, 1-16.
} 


\section{Cilj i problemi istraživanja}

Istraživanje je provedeno s ciljem utvrđivanja odnosa zborskoga pjevanja i dobrobiti pjevača amatera.

U skladu s oblikovanim ciljem postavljeni su sljedeći problemi istraživanja:

a) ispitati doprinosi li pjevanje u zboru subjektivnom osjećaju dobrobiti $u$ životu,

b) ispitati postoji li utjecaj zborskoga pjevanja na osjećaj fizičke dobrobiti pjevača amatera,

c) ispitati postoji li utjecaj zborskoga pjevanja na osjećaj emocionalne dobrobiti pjevača amatera,

d) ispitati postoji li utjecaj zborskoga pjevanja na osjećaj društvene dobrobiti pjevača amatera,

e) ispitati postoji li utjecaj zborskoga pjevanja na osjećaj duhovne dobrobiti pjevača amatera,

f) ispitati postoji li utjecaj dobi na subjektivan osjećaj dobrobiti,

g) ispitati postoji li utjecaj duljine pjevanja u zboru i subjektivnoga osjećaja dobrobiti,

h) ispitati postoji li utjecaj bavljenja drugim glazbenim aktivnostima na osjećaj dobrobiti,

i) ispitati postoji li povezanost procjene zadovoljstva životom i subjektivne procjene dobrobiti pjevača amatera.

\section{Sudionici}

Istraživanje je provedeno tijekom listopada 2019. godine u Osijeku na uzorku od 50 pjevača nagrađivanih amaterskih zborskih društava $(\check{Z}=44 ; M=6)$.

Pjevači koji su sudjelovali u istraživanju starosti su od 20 pa do više od 50 godina. Otprilike je sudjelovao podjednak broj sudionika po svakoj dobnoj skupini (jedno desetljeće). Najviše sudionika, njih $72 \%$ imaju visoku stručnu spremu, odnosno završen fakultet. Više od polovice (54 \%) pjevača ima do deset godina pjevačkog staža. 
Tablica 1. Struktura uzorka $(\mathrm{N}=50)$

\begin{tabular}{|c|c|c|c|}
\hline obilježje & kategorije & $\mathbf{f}$ & $\mathbf{\%}$ \\
\hline \multirow{3}{*}{ Spol } & Muško & 6 & $12,0 \%$ \\
\cline { 2 - 4 } & Žensko & 44 & $88,0 \%$ \\
\hline \multirow{4}{*}{ Dob } & $20-30$ & 10 & $20,0 \%$ \\
\cline { 2 - 4 } & $31-40$ & 11 & $22,0 \%$ \\
\cline { 2 - 4 } & $41-50$ & 16 & $32,0 \%$ \\
\cline { 2 - 4 } & Više od 51 & 13 & $26,0 \%$ \\
\hline \multirow{3}{*}{ Stručna sprema } & SSS & 6 & $12,0 \%$ \\
\cline { 2 - 4 } & VŠS & 8 & $16,0 \%$ \\
\hline \multirow{3}{*}{$\begin{array}{c}\text { Duljina pjevačkoga } \\
\text { staža }\end{array}$} & VSS & 36 & $72,0 \%$ \\
\cline { 2 - 4 } & Do 10 godina & 27 & $54,0 \%$ \\
\cline { 2 - 4 } & Do 20 godina & 13 & $26,0 \%$ \\
\cline { 2 - 4 } & Do 30 godina & 6 & $12,0 \%$ \\
\cline { 2 - 4 } & Do 40 godina & 3 & $6,0 \%$ \\
\cline { 2 - 4 } & Do 50 godina & 1 & $2,0 \%$ \\
\hline
\end{tabular}

\section{Instrument i postupak istraživanja}

Za potrebe istraživanja oblikovan je upitnik od četiri dijela. U prvome se dijelu nalaze pitanja koja se odnose na obilježja ispitanika (spol, dob, stručna sprema, duljina pjevanja u zboru, dosadašnje obrazovno glazbeno iskustvo). Drugi se dio upitnika odnosi na procjene zadovoljstva životom (Skala zadovoljstva životom - Satisfaction With Life Scale - SWLS). ${ }^{25}$ Prilagođena skala ima pet tvrdnji, a zadatak je sudionika da na skali odgovora Likertova tipa s pet stupnjeva ( 1 - uopće se ne slažem, 5 - u potpunosti se slažem) procijene zadovoljstvo životom. Koeficijent unutarnje konzistencije Cronbach alpha u ovome istraživanju pokazao je pouzdanost od 0,79. U trećem se dijelu zatvorenim, dihotomnim pitanjem željelo saznati doprinosi li pjevanje u zboru subjektivnom osjećaju dobrobiti u životu ispitanika, a pitanjima otvorenoga tipa nastojalo se precizirati koje dobrobiti ispitanici doživljavaju s obzirom na fizičko, emocionalno, društveno i duhovno područje. Ovaj dio mjernog instrumenta osmisli su autori ovoga rada. Četvrti dio upitnika odnosi se na Upitnik percipirane dobrobiti pjevanja ${ }^{26}$ koji ima 32 tvrdnje u kojima su ispitanici zaokruživanjem brojeva od 1 do 5 , na ljestvici Likertova tipa, označavali stupanj slaganja s navedenom tvrdnjom. Procjene su označavale sljedeće: 1 - izrazito se ne slažem; 2 - ne slažem se; 3 - niti se slažem, niti se ne slažem; 4 - slažem se; 5 - izrazito

\footnotetext{
${ }^{25}$ Usp. Ed DIENER i dr., The relationship between income subjective well-being. Relative or absolute?, Social Indicators Research, 28 (1993) 3, 195-223.

${ }^{26}$ Usp. Stephen CLIFT, Grenville HANCOX, The perceived benefits of singing. Findings from preliminary surveys of a univerity college choral society, The Journal of The Royal Society for the Promotion of Health, 121 (2001) 4, 248-256.
} 
se slažem. Upitnik se dijeli na četiri skale koje ispituju percipiranu dobrobit od pjevanja za fizičku, emocionalnu, socijalnu i duhovnu dobrobit. Skala fizičke dobrobiti ima deset tvrdnji, skala emocionalne dobrobiti devet tvrdnji, skala socijalne dobrobiti šest tvrdnji i skala duhovne dobrobiti sedam tvrdnji. Koeficijenti su unutarnje konzistencije Cronbach alpha u ovome istraživanju sljedeći: skala fizičke dobrobiti 0,91, skala emocionalne dobrobiti 0,90, skala socijalne dobrobiti 0,86 , skala duhovne dobrobiti 0,83 .

\section{Obrada podataka i upotrijebljene statističke metode}

Nakon anketiranja i prikupljanja podataka provedena je obrada podataka. Dobiveni su deskriptivni podaci za mjerene varijabli po česticama. Varijable su prikazane na temelju aritmetičkih sredina i standardnih devijacija čestica te pomoću frekvencija i postotka rezultata po česticama te aritmetičke sredine i standardne devijacije za ukupan rezultat za varijable zadovoljstvo životom, fizičku dobrobit, emocionalnu dobrobit, socijalnu i duhovnu dobrobit. Izračunani su koeficijenti korelacija između mjerenih varijabli.

$\mathrm{Za}$ obradu je podataka dobivenih kroz pitanja otvorenog tipa, primijenjen interpretativni pristup i kvalitativna analiza. Rabljena je redukcija podataka metodom usporedbe i kontrastiranja podataka te metoda »rezanja i lijepljenja« sličnih izjava zajedno, a najrelevantniji su odgovori citirani.

\section{Rezultati istraživanja i interpretacija}

U tablicama 1-5 prikazani su rezultati deskriptivne analize za percepciju fizičke, emocionalne, socijalne i duhovne dobrobiti pjevanja i zadovoljstvo životom.

Sudionici se uglavnom slažu s navedenim tvrdnjama (procjena 4 - slažem se). Najviše ih procjenjuje da su zadovoljni svojim životom ( $M=3,90 ; S D=0,65$, ukupno ih se $74 \%$ slaže i u potpunosti slaže), a najnižu procjenu dali su tvrdnji da ne bi ništa mijenjali kada bi mogli ponovno proživjeti život $(M=2,96$; SD $=0,95$; ukupno ih se $32 \%$ ne slaže i uopće ne slaže). Sudionici su naveli da su umjereno zadovoljni svojim životom ( $M=3,48$, raspon odgovora od 1 do 5 ).

U trećem su dijelu upitnika na pitanje Doprinosi li pjevanje u zboru Vašem osjećaju dobrobiti u životu svi sudionici odgovorili pozitivno, a što je razvidno i u njihovim odgovorima u narednim dijelovima upitnika.

Dodatno su odgovorima na sljedeće pitanje ispitanici pojasnili koje dobrobiti doživljavaju. Navode da im zborsko pjevanje utječe na bolju kondiciju, pravilno držanje tijela, jačanje trbušnih mišića, pravilno disanje, bolju kontrolu dijafragme, bolju kontrolu disanja te da im povećava kapacitet pluća. Ističu da 
Tablica 1. Deskriptivni podaci zadovoljstva životom

\begin{tabular}{|c|c|c|c|c|c|c|c|c|c|c|c|c|}
\hline \multirow[b]{2}{*}{ Tvrdnja } & \multirow[b]{2}{*}{$\mathbf{M}$} & \multirow[b]{2}{*}{ SD } & \multicolumn{2}{|c|}{$\begin{array}{c}\text { Uopće se } \\
\text { ne slažem }\end{array}$} & \multicolumn{2}{|c|}{$\begin{array}{c}\mathrm{Ne} \\
\text { slažem se }\end{array}$} & \multicolumn{2}{|c|}{$\begin{array}{c}\text { Niti se } \\
\text { slažem, } \\
\text { niti se ne } \\
\text { slažem }\end{array}$} & \multicolumn{2}{|c|}{ Slažem se } & \multicolumn{2}{|c|}{$\begin{array}{c}\text { U potpu- } \\
\text { nosti se } \\
\text { slažem }\end{array}$} \\
\hline & & & f & $\%$ & f & $\%$ & f & $\%$ & f & $\%$ & f & $\%$ \\
\hline $\begin{array}{l}\text { Na više sam načina } \\
\text { u životu došao blizu } \\
\text { svojega »idealnoga } \\
\text { života«. }\end{array}$ & 3,42 & 0,86 & - & - & 8 & 16 & 17 & 34 & 21 & 42 & 4 & 8 \\
\hline $\begin{array}{l}\text { Uvjeti u kojima } \\
\text { živim odlični su. }\end{array}$ & 3,68 & 0,91 & - & - & 6 & 12 & 13 & 26 & 22 & 44 & 9 & 18 \\
\hline $\begin{array}{l}\text { Zadovoljan sam } \\
\text { svojim životom. }\end{array}$ & 3,90 & 0,65 & - & - & - & - & 13 & 26 & 29 & 58 & 8 & 16 \\
\hline $\begin{array}{l}\text { Do sada sam } \\
\text { postigao najvažnije } \\
\text { stvari koje želim u } \\
\text { životu. }\end{array}$ & 3,46 & 0,93 & - & - & 9 & 18 & 15 & 30 & 20 & 40 & 6 & 12 \\
\hline $\begin{array}{l}\text { Kada bih mogao } \\
\text { život proživljavati } \\
\text { ponovno, ništa ne } \\
\text { bih mijenjao/la. }\end{array}$ & 2,96 & 0,95 & 2 & 4 & 14 & 28 & 21 & 42 & 10 & 20 & 3 & 6 \\
\hline $\begin{array}{l}\text { Zadovoljstvo } \\
\text { životom }\end{array}$ & 3,48 & 0,64 & & & & & & & & & & \\
\hline
\end{tabular}

pjevanjem doprinose boljem i razgovjetnijem izgovoru i boljoj dikciji. Ispitanici navode da nakon probe zbora osjećaju fizičko rasterećenje i osjećaju poletnost te kako imaju dojam smanjenja fizičkih manifestacija stresa.

$\mathrm{S}$ emocionalnoga gledišta pjevači navode da im pjevanje u zboru poboljšava raspoloženje, izravno utječe na osjećaj radosti, sreće $i$ zadovoljstva, smanjuje nakupljeni emocionalni stres i emocionalno rasterećuje od nakupljene napetosti i briga svakodnevice. Ispitanici također ističu da im je pjevanje u zboru utjeha $\mathrm{i}$ distrakcija od problema te da se osjećaju emocionalno ispunjeni tijekom proba pjevanja. Neki od ispitanika navode da su pjevanjem u zboru prevladali nelagodu i strah od javnih nastupa. Jedan ispitanik ističe da je poseban emocionalni doživljaj pjevanje prekrasnih skladbi.

$S$ društvenoga gledišta navode da im pjevanje u zboru utječe na socijalizaci$j u$. Sudjelovanje u zboru daje im osjećaj pripadnosti grupi te utječe na njihovo samopouzdanje i otvorenost u komunikaciji. Ukazuju na to da su kroz zborske aktivnosti upoznali nove, razlicite ljude, ostvarili brojna poznanstva $i$ prijateljstva, ističu druženja na pjevačkim probama i izvan njih, ali i naglašavaju da su postali fleksibilniji prema različitim karakterima. Ističu da imaju osjećaj pripadnosti pjevačkom društvu i pjevačkoj obitelji i stremljenja $k$ istom cilju te osjećaj zadovoljstva prilikom postizanja toga cilja. Timski rad i zajedništvo te prijateljstvo i druženje najzastupljenija su dobrobit koju ispitanici navode $\mathrm{u}$ 
društvenome području. Također ističu da su putovanjima obogatili svoj život te kako se osjećaju ponosno što sudjelovanjem doprinose svjetskim postignućima priznatoga i poznatoga pjevačkoga društva.

Ispitanici najčešće navode da im pjevanje u zboru daje unutarnji mir i ispunjenost te svojevrsno duhovno uzdizanje i bogatstvo. Ističu da je uživanje u glazbi, posebice duhovnoga sadržaja, poseban osjećaj koji nije moguće povezani niti s jednim drugim iskustvom.

Pomoću deset tvrdnji ispitani su stavovi pjevača o fizičkoj dobrobiti od pjevanja. Rezultati su u tablici 2.

Tablica 2. Deskriptivni podaci percepcije fizičke dobrobiti pjevanja

\begin{tabular}{|c|c|c|c|c|c|c|c|c|c|c|c|c|}
\hline \multirow[b]{2}{*}{ Tvrdnja } & \multirow[b]{2}{*}{$\mathbf{M}$} & \multirow[b]{2}{*}{ SD } & \multicolumn{2}{|c|}{$\begin{array}{l}\text { Izrazito } \\
\text { se ne } \\
\text { slažem }\end{array}$} & \multicolumn{2}{|c|}{$\begin{array}{c}\mathrm{Ne} \\
\text { slažem se }\end{array}$} & \multicolumn{2}{|c|}{$\begin{array}{c}\text { Niti se } \\
\text { slažem, } \\
\text { niti se ne } \\
\text { slažem }\end{array}$} & \multicolumn{2}{|c|}{ Slažem se } & \multicolumn{2}{|c|}{$\begin{array}{c}\text { Izrazito } \\
\text { se slažem }\end{array}$} \\
\hline & & & f & $\%$ & f & $\%$ & f & $\%$ & f & $\%$ & f & $\%$ \\
\hline $\begin{array}{l}\text { Pjevanje u zboru } \\
\text { poboljšava mi kontrolu } \\
\text { disanja. }\end{array}$ & 4,30 & 0,65 & - & - & - & - & 5 & 10 & 25 & 50 & 20 & 40 \\
\hline $\begin{array}{l}\text { Pjevanje u zboru čini me } \\
\text { budnijim, energičnijim, } \\
\text { aktivnijim. }\end{array}$ & 4,34 & 0,69 & - & - & - & - & 6 & 12 & 21 & 42 & 23 & 46 \\
\hline $\begin{array}{l}\text { Pjevanje u zboru } \\
\text { poboljšava mi držanje } \\
\text { tijela. }\end{array}$ & 4,08 & 0,75 & - & - & 1 & 2 & 9 & 18 & 25 & 50 & 15 & 30 \\
\hline $\begin{array}{l}\text { Pjevanje u zboru } \\
\text { poboljšava mi kapacitet } \\
\text { pluća. }\end{array}$ & 4,10 & 0,74 & - & - & 1 & 2 & 8 & 16 & 26 & 52 & 15 & 30 \\
\hline $\begin{array}{l}\text { Pomoću pjevanja ojačao } \\
\text { sam dijafragmu i dišem } \\
\text { punim plućima. }\end{array}$ & 4,02 & 0,85 & - & - & 3 & 6 & 8 & 16 & 24 & 48 & 15 & 30 \\
\hline $\begin{array}{l}\text { Pjevanjem u zboru } \\
\text { osjećam se općenito bolje } \\
\text { i jače. }\end{array}$ & 4,24 & 0,80 & - & - & 1 & 2 & 8 & 16 & 19 & 38 & 22 & 44 \\
\hline $\begin{array}{l}\text { Zbog pjevanja mi se } \\
\text { poboljšala kvaliteta glasa } \\
\text { i sposobnost kontrole } \\
\text { glasa. }\end{array}$ & 4,28 & 0,67 & - & - & - & - & 6 & 12 & 24 & 48 & 20 & 40 \\
\hline $\begin{array}{l}\text { Pjevanjem jačam mišiće } \\
\text { trbuha i prsa. }\end{array}$ & 3,90 & 0,76 & - & - & - & - & 17 & 34 & 21 & 42 & 12 & 24 \\
\hline $\begin{array}{l}\text { Pjevanjem utječem na } \\
\text { krvožilni sustav i jačam } \\
\text { srce. }\end{array}$ & 3,96 & 0,78 & - & - & 1 & 2 & 13 & 26 & 23 & 46 & 13 & 26 \\
\hline $\begin{array}{l}\text { Pjevanje mi pomaže u } \\
\text { pravilnom disanju. }\end{array}$ & 4,22 & 0,65 & - & - & - & - & 6 & 12 & 27 & 54 & 17 & 34 \\
\hline Fizička dobrobit & 4,14 & 0,54 & & & & & & & & & & \\
\hline
\end{tabular}


Premda se sa svim tvrdnjama slažu, sudionici najčešće navode da ih pjevanje u zboru čini budnijim, energičnijim, aktivnijim $(M=4,34 ; S D=0,69)$ i poboljšava im kontrolu disanja $(M=4,30 ; S D=0,65)$. Uz kontrolu disanja i sposobnost kontrole i kvalitete $(\mathrm{M}=4,28 ; \mathrm{SD}=0,67)$ visokim prosječnim ocjenama $(M=4,24 ; S D=0,80)$ procjenjuju tvrdnju da se pjevanjem u zboru općenito osjećaju bolje i jače.

U devet sljedećih tvrdnji ispitani su stavovi pjevača o emocionalnoj dobrobiti od pjevanja. Rezultati su prikazani u tablici 3.

Tablica 3. Deskriptivni podaci percepcije emocionalne dobrobiti pjevanja

\begin{tabular}{|c|c|c|c|c|c|c|c|c|c|c|c|c|}
\hline \multirow[b]{2}{*}{ Tvrdnja } & \multirow[b]{2}{*}{$\mathbf{M}$} & \multirow[b]{2}{*}{ SD } & \multicolumn{2}{|c|}{$\begin{array}{l}\text { Izrazito } \\
\text { se ne } \\
\text { slažem }\end{array}$} & \multicolumn{2}{|c|}{$\underset{\mathrm{Ne}}{\text { slažem se }}$} & \multicolumn{2}{|c|}{$\begin{array}{c}\text { Niti se } \\
\text { slažem, } \\
\text { niti se ne } \\
\text { slažem }\end{array}$} & \multicolumn{2}{|c|}{ Slažem se } & \multicolumn{2}{|c|}{$\begin{array}{c}\text { Izrazito } \\
\text { se slažem }\end{array}$} \\
\hline & & & f & $\%$ & f & $\%$ & f & $\%$ & f & $\%$ & f & $\%$ \\
\hline $\begin{array}{l}\text { Pjevanje u zboru podiže } \\
\text { mi raspoloženje, čini me } \\
\text { pozitivnim i sretnim. }\end{array}$ & 4,72 & 0,45 & - & - & - & - & - & - & 14 & 28 & 36 & 72 \\
\hline $\begin{array}{l}\text { Pjevanje u zboru } \\
\text { predstavlja emocionalni } \\
\text { trening i potiče emocije. }\end{array}$ & 4,54 & 0,61 & - & - & - & - & 3 & 6 & 17 & 34 & 30 & 60 \\
\hline $\begin{array}{l}\text { Pjevanje u zboru pomaže } \\
\text { mi u smanjivanju i/ili } \\
\text { oslobađanju od stresa i } \\
\text { napetosti. }\end{array}$ & 4,66 & 0,52 & - & - & - & - & 1 & 2 & 15 & 30 & 34 & 68 \\
\hline $\begin{array}{l}\text { Pomoću pjevanja } \\
\text { osjećam se opuštenije/ } \\
\text { smirenije. }\end{array}$ & 4,58 & 0,54 & - & - & - & - & 1 & 2 & 19 & 38 & 30 & 60 \\
\hline $\begin{array}{l}\text { Pjevanje u zboru } \\
\text { čini me aktivnijim i } \\
\text { entuzijastičnijim. }\end{array}$ & 4,40 & 0,64 & - & - & - & - & 4 & 8 & 22 & 44 & 24 & 48 \\
\hline $\begin{array}{l}\text { Pjevanje u zboru odvraća } \\
\text { mi pažnju od poslovnih } \\
\text { briga i obveza. }\end{array}$ & 4,30 & 0,79 & - & - & 1 & 2 & 7 & 14 & 18 & 36 & 24 & 48 \\
\hline $\begin{array}{l}\text { Pjevanje u zboru na } \\
\text { mene djeluje terapeutski. }\end{array}$ & 4,52 & 0,65 & - & - & 1 & 2 & 1 & 2 & 19 & 38 & 29 & 58 \\
\hline $\begin{array}{l}\text { Pjevanjem u zboru } \\
\text { izražavam svoje emocije. }\end{array}$ & 4,28 & 0,73 & - & - & 1 & 2 & 5 & 10 & 23 & 46 & 21 & 42 \\
\hline $\begin{array}{l}\text { Pjevanje u zboru } \\
\text { poboljšava mi } \\
\text { samopouzdanje. }\end{array}$ & 4,20 & 0,81 & - & - & 1 & 2 & 9 & 18 & 19 & 38 & 21 & 42 \\
\hline Emocionalna dobrobit & 4,47 & 0,48 & & & & & & & & & & \\
\hline
\end{tabular}

Sve ponuđene izjave ostvarile su visoku razinu slaganja. Sudionici najčešće navode da im pjevanje u zboru podiže raspoloženje, čini ih pozitivnima i sretnima $(M=4,72 ; S D=0,45$; ukupno ih se $100 \%$ slaže i izrazito slaže), pomaže 
im u smanjivanju i/ili oslobađanju od stresa i napetosti $(M=4,66 ; S D=0,52$; ukupno ih se 98 \% slaže i izrazito slaže), osjećaju se opuštenije/smirenije (M $=4,58 ; \mathrm{SD}=0,54$; ukupno ih se $98 \%$ slaže i izrazito slaže) te djeluje na njih terapeutski ( $M=4,52, \mathrm{SD}=0,65$; ukupno ih se $96 \%$ slaže i izrazito slaže).

Iz sljedećih šest tvrdnji vidljivi su stavovi pjevača o socijalnoj dobrobiti od zborskoga pjevanja. Rezultati su vidljivi u tablici 4.

Tablica 4. Deskriptivni podaci percepcije socijalne dobrobiti pjevanja

\begin{tabular}{|c|c|c|c|c|c|c|c|c|c|c|c|c|}
\hline \multirow[b]{2}{*}{ Tvrdnja } & \multirow[b]{2}{*}{ M } & \multirow[b]{2}{*}{ SD } & \multicolumn{2}{|c|}{$\begin{array}{l}\text { Izrazito } \\
\text { se ne } \\
\text { slažem }\end{array}$} & \multicolumn{2}{|c|}{$\begin{array}{c}\mathrm{Ne} \\
\text { slažem se }\end{array}$} & \multicolumn{2}{|c|}{\begin{tabular}{|c|} 
Niti se \\
slažem, \\
niti se ne \\
slažem
\end{tabular}} & \multicolumn{2}{|c|}{ Slažem se } & \multicolumn{2}{|c|}{$\begin{array}{l}\text { Izrazito } \\
\text { se slažem }\end{array}$} \\
\hline & & & f & $\%$ & f & $\%$ & f & $\%$ & f & $\%$ & $\mathbf{f}$ & $\%$ \\
\hline $\begin{array}{l}\text { Kroz pjevanje u zboru } \\
\text { stekao sam brojna } \\
\text { poznanstva. }\end{array}$ & 4,34 & 0,75 & - & - & - & - & 8 & 16 & 17 & 34 & 25 & 50 \\
\hline $\begin{array}{l}\text { Kroz pjevanje u zboru } \\
\text { stekao sam nove } \\
\text { prijatelje. }\end{array}$ & 4,38 & 0,73 & - & - & - & - & 7 & 14 & 17 & 34 & 26 & 52 \\
\hline $\begin{array}{l}\text { Kroz pjevanje u zboru } \\
\text { uživam u druženju s } \\
\text { prijateljima koje sam } \\
\text { imao prije nego što sam } \\
\text { se pridružio zboru. }\end{array}$ & 3,72 & 1,09 & 3 & 6 & 3 & 6 & 11 & 22 & 21 & 42 & 12 & 24 \\
\hline $\begin{array}{l}\text { Pjevanje u zboru } \\
\text { omogućuje zabavu, } \\
\text { dobru i prijateljsku } \\
\text { atmosferu. }\end{array}$ & 4,38 & 0,75 & - & - & 1 & 2 & 5 & 10 & 18 & 36 & 26 & 52 \\
\hline $\begin{array}{l}\text { Pjevanjem u zboru } \\
\text { povezujem se s ljudima iz } \\
\text { zbora nakon pjevanja. }\end{array}$ & 4,24 & 0,89 & - & - & 3 & 6 & 6 & 12 & 17 & 34 & 24 & 48 \\
\hline $\begin{array}{l}\text { Pjevanje u zboru daje mi } \\
\text { osjećaj pripadnosti grupi. }\end{array}$ & 4,26 & 0,63 & - & - & - & - & 5 & 10 & 27 & 54 & 18 & 36 \\
\hline Socijalna dobrobit & 4,22 & 0,63 & & & & & & & & & & \\
\hline
\end{tabular}

Ispitanici se slažu sa svim tvrdnjama o socijalnoj dobrobiti navodeći da im je pjevanje u zboru omogućilo zabavu, dobru i prijateljsku atmosferu te su putem ove aktivnosti stekli nove prijatelje $(M=4,38)$. Također se izrazito slažu i slažu $\mathrm{s}$ tvrdnjama da im pjevanje u zboru daje osjećaj pripadnosti grupi $(\mathrm{M}=4,26$; $\mathrm{SD}=0,633)$ te da se povezuju s ljudima iz zbora i nakon proba $(\mathrm{M}=4,24 ; \mathrm{SD}=$ $0,894)$.

Sljedeće tvrdnje pokazuju stavove pjevača o duhovnoj dobrobiti zborskoga pjevanja. Rezultati su u tablici 5. 
Tablica 5. Deskriptivni podaci percepcije duhovne dobrobiti pjevanja

\begin{tabular}{|c|c|c|c|c|c|c|c|c|c|c|c|c|}
\hline \multirow[b]{2}{*}{ Tvrdnja } & \multirow[b]{2}{*}{$\mathbf{M}$} & \multirow[b]{2}{*}{ SD } & \multicolumn{2}{|c|}{$\begin{array}{l}\text { Izrazito } \\
\text { se ne } \\
\text { slažem }\end{array}$} & \multicolumn{2}{|c|}{$\underset{\text { slažem se }}{\mathrm{Ne}}$} & \multicolumn{2}{|c|}{\begin{tabular}{|c|} 
Niti se \\
slažem, \\
niti se ne \\
slažem
\end{tabular}} & \multicolumn{2}{|c|}{ Slažem se } & \multicolumn{2}{|c|}{$\begin{array}{c}\text { Izrazito } \\
\text { se slažem }\end{array}$} \\
\hline & & & f & $\%$ & f & $\%$ & f & $\%$ & f & $\%$ & f & $\%$ \\
\hline $\begin{array}{l}\text { Pjevanje u zboru } \\
\text { ima razne dobrobiti: } \\
\text { pozitivniji osjećaji } \\
\text { prema životu, terapijski, } \\
\text { harmonija, manje } \\
\text { stresa, veća povezanost, } \\
\text { vrijednost, doprinos } \\
\text { društvu. }\end{array}$ & 4,46 & 0,58 & - & - & - & - & 2 & 4 & 23 & 46 & 25 & 50 \\
\hline $\begin{array}{l}\text { Pjevajući u zboru, } \\
\text { duhovno se uzdižem. }\end{array}$ & 4,12 & 0,90 & 1 & 2 & 1 & 2 & 8 & 16 & 21 & 42 & 19 & 38 \\
\hline $\begin{array}{l}\text { Pjevanje u zboru ima } \\
\text { nematerijalne učinke koji } \\
\text { se ne mogu opisati ni } \\
\text { objasniti. }\end{array}$ & 4,44 & 0,81 & 1 & 2 & - & - & 4 & 8 & 16 & 32 & 29 & 58 \\
\hline $\begin{array}{l}\text { Pjevanje religiozne glazbe } \\
\text { povećava moja duhovna/ } \\
\text { religijska uvjerenja. }\end{array}$ & 3,32 & 1,22 & 4 & 8 & 9 & 18 & 14 & 28 & 13 & 26 & 10 & 20 \\
\hline $\begin{array}{l}\text { Pjevanje u zboru potiče } \\
\text { me na razmišljanje o } \\
\text { religiji, povijesti, kulturi. }\end{array}$ & 3,44 & 1,15 & 5 & 10 & 3 & 6 & 15 & 30 & 19 & 38 & 8 & 16 \\
\hline $\begin{array}{l}\text { Pjevanje u zboru čini me } \\
\text { duhovno bogatijim. }\end{array}$ & 4,14 & 0,81 & - & - & 1 & 2 & 10 & 20 & 20 & 40 & 19 & 38 \\
\hline $\begin{array}{l}\text { Pjevajući u zboru, } \\
\text { osjećam se na duhovni } \\
\text { način povezaniji s ostalim } \\
\text { članovima zbora. }\end{array}$ & 3,86 & 0,78 & - & - & - & - & 19 & 38 & 19 & 38 & 12 & 24 \\
\hline Duhovna dobrobit & 3,97 & 0,64 & & & & & & & & & & \\
\hline
\end{tabular}

Od navedenih tvrdnji sudionici se najmanje slažu s time da im pjevanje religiozne glazbe povećava duhovna/religijska uvjerenja $(M=3,32 ; \mathrm{SD}=1,220$; ukupno ih se $26 \%$ i ne slaže i izrazito ne slaže) i da ih pjevanje u zboru potiče na razmišljanje o religiji, povijesti, kulturi $(M=3,44, \mathrm{SD}=1,146$; ukupno ih se $16 \%$ ne slaže i izrazito ne slaže).

Što se tiče ukupnih procjena dobivenih po skalama, sudionici procjenjuju da najviše dobrobiti od zborskoga pjevanja imaju za emocionalni aspekt dobrobiti $(\mathrm{M}=4,47 ; \mathrm{SD}=0,476)$, zatim socijalni aspekt $(\mathrm{M}=4,22 ; \mathrm{SD}=0,625)$, potom fizički aspekt dobrobiti $(\mathrm{M}=4,14 ; \mathrm{SD}=0,543)$, a najmanje za duhovni aspekt dobrobiti $(\mathrm{M}=3,97$; $\mathrm{SD}=0,640)$.

Povezanost dobi, duljine pjevačkoga staža, iskustva bavljenja glazbom, zadovoljstva životom i percepcije dobrobiti pjevanja iskazana je u tablici 6 . 
Tablica 6. Koeficijenti korelacije između dobi, duljine pjevačkoga staža, iskustva bavljenja glazbom, zadovoljstva životom i percepcije dobrobiti pjevanja

\begin{tabular}{|l|c|c|c|c|c|c|c|c|}
\hline & $\mathbf{1}$ & $\mathbf{2}$ & $\mathbf{3}$ & $\mathbf{4}$ & $\mathbf{5}$ & $\mathbf{6}$ & $\mathbf{7}$ & $\mathbf{8}$ \\
\hline 1. Dob & - & $0,29^{*}$ & 0,26 & 0,09 & $-0,25$ & 0,07 & $-0,06$ & $-0,02$ \\
\hline 2. Duljina pjevačkoga staža & & - & 0,03 & $-0,21$ & $-0,06$ & $-0,02$ & 0,25 & 0,12 \\
\hline 3. Iskustvo bavljenja glazbom & & & - & $-0,06$ & $-0,11$ & 0,08 & 0,00 & 0,12 \\
\hline 4. Zadovoljstvo životom & & & & - & 0,23 & 0,23 & 0,14 & 0,13 \\
\hline 5. Fizička dobrobit & & & & & - & $0,56^{* * *}$ & $0,48^{* * * *}$ & $0,56^{* * * *}$ \\
\hline 6. Emocionalna dobrobit & & & & & & - & $0,33^{*}$ & $0,56^{* *}$ \\
\hline 7. Socijalna dobrobit & & & & & & & - & $0,39^{* * *}$ \\
\hline 8. Duhovna dobrobit & & & & & & & & - \\
\hline
\end{tabular}

Napomena: $p<0,01^{* * *} ; \mathrm{p}<0,05^{*}$

Rezultati ispitivane povezanosti navedenih varijabli pokazali su značajnu povezanost između dobi i duljine pjevačkoga staža $(r=0,29 ; p<0,05)$, pri čemu stariji sudionici imaju više pjevačkoga staža. Suprotno pretpostavljenome, nije se pokazala značajnom povezanost zadovoljstva životom i ispitanih aspekata percipirane dobrobiti od pjevanja.

Aspekti percipirane dobrobiti od zborskoga pjevanja značajno su međusobno povezani. Aspekti percipirane fizičke dobrobiti značajno su umjereno povezani s aspektima emocionalne dobrobiti $(\mathrm{r}=0,56 ; \mathrm{p}<0,01)$ i s aspektima duhovne dobrobiti $(\mathrm{r}=0,56 ; \mathrm{p}<0,01)$. Sudionici koji visokom ocjenjuju fizičku dobrobit također visoko ocjenjuju emocionalnu i duhovnu dobrobit. Također postoji značajna umjerena povezanost između percipirane emocionalne i duhovne dobrobiti $(\mathrm{r}=0,56 ; \mathrm{p}<0,05)$, odnosno da sudionici koji percipiraju emocionalnu dobrobit višom tako percipiraju i duhovnu dobrobit od pjevanja. Postoji niska povezanost percipirane emocionalne i socijalne dobrobiti $(\mathrm{r}=$ $0,33 ; \mathrm{p}<0,05)$ te socijalne i duhovne dobrobiti $(\mathrm{r}=0,39 ; \mathrm{p}<0,01)$.

\section{Zaključak}

Dobiveni su rezultati ovoga istraživanja potvrdili izvješća recentnih istraživanja i iskustva brojnih znanstvenika diljem svijeta koji naglašavaju izniman potencijal glazbene umjetnosti, posebice zborskoga pjevanja na subjektivnu dobrobit pojedinca. Taj neraskidiv odnos između glazbe, pjevanja i pojedinca te društvene zajednice njeguje se putem višestruke dobrobiti koju pjevači osjećaju sudjelujući u zborskim aktivnostima. Svi pjevači unisono naglašavaju da doživljavaju osobnu dobrobit od pjevanja u zboru. Procjenjuju da je najsnažnija dobrobit od zborskoga pjevanja povezana s emocionalnim aspektom, zatim socijalnim, fizičkim i najmanje s područjem duhovne dobrobiti. Pjevači najčešće navode da im pjevanje u zboru podiže raspoloženje, čini ih pozitivnima i 
sretnima i pomaže im u smanjivanju stresa i napetosti i oslobađanju od njih te djeluje na njih terapeutski. Posebno ističu socijalizacijsku važnost koju zborsko pjevanje ima u njihovu životu te dominantno navode prijateljstvo i druženje kao najzastupljeniju dobrobit u socijalizacijskom smislu. Ukazuju na to da im sudjelovanje u zboru daje osjećaj pripadnosti grupi i zajednici. Naglašavaju da pjevanje u zboru utječe na njihovo samopouzdanje i otvorenost prema novim poznanstvima, ali ih i čini fleksibilnijim prema drugima i drugačijem. Posebno ističu važnost timskoga rada koje je imanentno zborskim probama i nastupima te zadovoljstvo i ponos koje osjećaju prigodom postizanja zajedničkoga cilja.

Znanstveni se doprinos rada, osim što je to prvo istraživanje ostvareno na uzorku pjevača iz Hrvatske, ogleda u rezultatu istraživanja da zborsko pjevanje, osim primarne umjetničke funkcije, pridonosi emocionalnoj, društvenoj i fizičkoj dobrobiti sudionika kao važnom cilju slobodnih aktivnosti i života uopće. Aktualizacija saznanja iz provedenoga istraživanja trebala bi dodatno popularizirati zborsko pjevanje i ponuditi takav oblik slobodne aktivnosti i specifičnim društvenim skupinama. 


\section{Tihana Škojo*}

\section{The Relationship Between Choirs' Activities and the Wellbeing of Amateur}

\section{Summary}

Despite current occurrences in society, which systematically influence the decrease of leisure time among all social groups, choral singing has maintained its vast, rich tradition and secured its place as the most popular leisure time activity. Through choral singing, individuals successfully find ways to satisfy their need for activity, socialization, music, and musical creativity as well as to additionally affirm their position in society. By exploring previous research, the relationship between musical activities and wellbeing of individuals is emphasized. We point out to the connection between positive emotions and singing in a choir, which is evident from the change of the singer's physiological status, the development of musical skills and the improvement of the singer's psychophysical condition. Based on the experience of previously conducted international research, this research has been conducted to determine the relationship between choral singing activities and the wellbeing of amateur singers. The research examined the length of singing experience, life satisfaction, the contribution of singing to the subjective sense of well-being, and the perceived assessment of physical, emotional, social, and spiritual well-being. The results of the conducted study affirm numerous personal improvements of singers due to singing in a choir. The benefit of choral singing, apart from it having a primary artistic function, is that it contributes to emotional, societal, and physical wellbeing as an essential goal of leisure time activities and life in general.

Key words: choral singing, leisure time, wellbeing.

(na engl. prev. Tihana Škojo)

\footnotetext{
* Tihana Škojo, PhD, Assis. Prof., Josip Juraj Strossmayer University of Osijek; Academy of Arts and Culture; Address: Kralja Petra Svačića 1F, HR-31000 Osijek, Croatia; E-mail: tihana.skojo@ uaos.hr.
} 